Nig. J. Anim. Prod. 2021, 48(3): 41 - 48.doi.org/10.51791/njap.v48i3.2957

Nigerian Journal of Animal Production

(1) Nigerian Society for Animal Production

\title{
Radiographic evaluation of the lower forelimbs of Nigerian horses presenting with lower forelimb lameness in Obollo-Afor horse lairage
}

Ogbanya, K. C., Eze, C. A. and Nnaji, T. O.

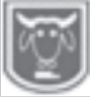

Department of Veterinary Surgery, Faculty of Veterinary Medicine, University of Nigeria, Nsukka

Abstract

*Corresponding author: kenneth.ogbanya@unn.edu.ng

Lower forelimb lameness is an important health issue with serious economic impact in equine husbandry. Radiographic confirmation of the cause of lameness is a necessity in lameness management and treatment. The current study was aimed to radiographically identify the possible skeletal causes of lower forelimb lameness in Nigerian horses at Obollo-Afor horse lairage. During the period of May 2019 to July 2019, 20 horses of both sexes between the ages of 5 to 10 years presenting with lower forelimb lameness were selected following clinical examination. The forelimbs of the selected horses were subsequently subjected to radiographic examination. Three horses (15\%) out of the 20 sampled were radiographically identified as having neoplastic-like lesions. One horse (5\%) had luxation of interphalangeal joint. The radiographic dorsopalmer view showed bilateral side bones in 35\% of the horses. Ventropalmer radiographic view revealed a unilateral side bone in four horses (20\%) out of the 20 horses sampled. Diagnosed lower forelimb lameness in the sampled horses could have been caused by the observed osteopathological conditions.

Keywords: Nigerian horse, forelimb lameness, radiography

L'Évaluation radiographique des membres antérieurs inférieurs des chevaux Nigérians se présentant avec la boite inférieure de membre antérieur dans le repaire de cheval d'Obollo-Afor

\section{Résumé}

La diminution de la boiterie des membres antérieurs est un problème de santé important qui a de graves répercussions économiques sur l'élevage équidé. La confirmation radiographique de la cause de la boitosité est une nécessité dans la gestion et le traitement de boiteux. L'étude actuelle visait à identifier par radiographie les causes squelettiques possibles de la boite inférieure du membre antérieur chez les chevaux nigérians à l'antre des chevaux d'ObolloAfor. Au cours de la période de mai 2019 à juillet 2019, 20 chevaux des deux sexes âgés de 5 à 10 ans présentant une boitosité inférieure du membre antérieur ont été sélectionnés à la suite d'un examen clinique. Les membres antérieurs des chevaux sélectionnés ont ensuite été soumis à un examen radiographique. Trois chevaux (15\%) sur les 20 échantillons échantillonnés ont été radiographiquement identifiés comme ayant des lésions néoplastiques-comme. Un cheval (5\%) avait luxation de joint interphalangeal. La vue radiographique de dorsopalmer a montré les os latéraux bilatéraux dans 35\% des chevaux. La vue radiographique de Ventropalmer a indiqué un os latéral unilatéral dans quatre chevaux (20\%) sur les 20 chevaux échantillonnés. La boite inférieure diagnostiquée d'aelimb dans les chevaux échantillonnés pourrait avoir été provoquée par les conditions ostéopathologiques observées.

Mots-clés: Cheval Nigérian, boiteuse de membre antérieur, radiographie 


\section{Introduction}

Horses have been of a great importance to human in many different aspects of life such as draft, transport, sports, ceremonial exhibitions, research purposes, Agriculture, warfare, crowed control, as food (meat) and source of variety of products (milk, hide, bone meal) and medicine (Greene, 2009). Equine limb is a unique structure and dominant site for lameness, because it is exposed to a tremendous amount of strain and stress in performance horse. A multitude of disorders can affect the forelimbs and cause lameness (Reilly, 1995). Lameness is defined as an abnormal stance or gait caused by either a structural or a functional disorder of the locomotor system (Adams, 2016). Lameness is not a disease per se but a clinical sign. It is a manifestation of pain, mechanical restrictions, causing alteration of stance or gait, or locomotory problem (Adams, 2016). This alteration may be mild and only noted at high intensity levels of exercise or may be severe and noted when the horse is walking or standing (Black et al., 2013). Lameness can be caused by trauma (single event or repetitive work), congenital or acquired anomalies, developmental defects, infections, metabolic disturbances, circulatory, and nervous disorder or any combination of these (Fekadu et al., 2015). All types of horses are susceptible to lameness, and sooner or later, most horses are affected by it (Garber and Stanton, 2000). Clinically, lameness is recognized as an abnormality in the way a horse moves or stands. It is usually associated with a painful musculoskeletal condition or a mechanical abnormality affecting locomotion (Garber and Stanton, 2000). Radiology is an imaging modality most commonly used for determining bone quality and disorders (Vanderperren and Saunder, 2009). It is a standard diagnostic tool used to diagnose bone disorders in equine. Radiographic examination gives tremendous insight into the relationship between the structures within the foot and between the foot and distal limb (Thrill, 2002). Reports have shown that greater percentage of forelimb lameness emanates from the lower forelimb region. The objective of this study was therefore to radiographically identify the possible skeletal causes of lower forelimb lameness in Nigerian horses at Obollo-Afor horse lairage.

\section{Materials and methods}

During the period of May 2019 to July 2019, twenty (20) horses of both sexes between the age of 5 to 10 years presenting with lower forelimb lameness were selected following clinical examination. The study was conducted on Nigerian horses at Obollo-Afor horse lairage in Enugu state, South Eastern Nigeria. These Nigerian horses are a collection of mixed Arewa breeds and their crosses with the Arabian, Dongola, Barb-Arab and Sudanese breeds which are not distinguishable from one another based on any specific breed characteristics (Ihedioha and Agina, 2013). Twenty (20) horses of both sexes between the age of 5 to 10 years presenting with lower forelimb lameness were selected following clinical examination. The selected horses were subsequently subjected to radiographic examination.

Confirmation of lower forelimb lameness using abaxial sesamoid nerve block

Abaxial sesamoid nerve block was performed on the outside edges of the sesamoid bones above the fetlock joint were the medial and lateral palmer nerve divides. Twenty-two gauge (22 gauge) one-inch needle was used to place $5 \mathrm{mls}$ of lidocaine hydrochloride over both the medial and lateral palmer nerves. This blocks provided analgesia from the fetlock joint down the hoof (i.e., foot, first, second and third phalanxes).

Lower forelimb (i.e., from the fetlock joint to the hoof) lameness was confirmed when 


\section{Ogbanya, Eze and Nnaji}

the forelimb lameness was abolished after the nerve blocks were performed (Dyson and Romero, 1993; Pilesworth and Dyson, 2015).

\section{Radiological examination}

A portable $\mathrm{x}$-ray generator with exposure factor of 3.2 Amp and 84 Kilvoltage was suspended on the $\mathrm{x}$-ray tripod stand and $\mathrm{x}$ ray cassette held behind the foot using cassette holder. The hooves were cleaned thoroughly with water and hoof brush. Different views of the lower forelimb feet were obtained by passing the beam through specific area of interest. A block was used to elevate the foot above the ground so as to position the foot on center of cassette. After taking the exposure, the films were then processed and the radiographs were interpreted.

\section{Data management and analysis}

Presence or absence of a particular radiographic lesion were recorded as " 1 " (meaning "Yes" for presence), and " 0 " (meaning "No" for absence). Percentage distributions of the radiographic lesions were computed as: Proportion of the number of positive observations of each lesion type divided by the total number of feet sampled, multiplied by 100 to express it as a percentage.

\section{Results \\ Radiographic findings}

Three horses $(15 \%)$ out of the 20 horses sampled showed evidence of neoplastic lesions on the affected proximal phalanx (Fig. 1). Radiological examination demonstrated aggressive periosteal reactive lesions on the affected areas, extensive disorganized bone proliferation (exostosis) of the phalanxuh (Fig. 1). The radiological assessment also revealed extensive area of bone lysis of the first phalanx (osteolytic lesion) (Fig. 1). A diagnosis of bone neoplastic-like lesions was made. However, bone biopsy or histopathological examination was not carried out because of lack of client consent for surgical biopsy collection. Thus, we were unable to identify the type of neoplasm involved. One horse (5\%) had luxation of interphalangeal joint. Radiography showed phalangeal joint luxation with no evidence of bone fracture (Fig. 2). Seven horses (35\%) had bilateral side bones. The radiographic dorsopalmer view showed bilateral side bones (Fig. 3). Ventropalmer radiographic view revealed a unilateral side bone in four horses $(20 \%)$ out of the 20 sampled (Fig. 4). Out of the 20 horses examined, 15 (75\%) were positive for radiographic bone pathology. Ten male $(50 \%)$ and five female $(25 \%)$ horses showed evidence of radiographic bone pathology. Prevalence rates of radiographic bone pathology observed were summarized in Table 1, while Table 2 is a summary of the number of male and female horses that showed positive for radiographic bone pathology.

One horse (5\%) had luxation of interphalangeal joint. Radiography showed phalangeal joint luxation with no evidence of bone fracture (Fig. 2). Seven horses $(35 \%)$ had bilateral side bones. The radiographic dorsopalmer view showed bilateral side bones (Fig. 3). Ventropalmer radiographic view revealed a unilateral side bone in four horses $(20 \%)$ out of the 20 sampled (Fig. 4). Out of the 20 horses examined, $15(75 \%)$ were positive for radiographic bone pathology. Ten male $(50 \%)$ and five female $(25 \%)$ horses showed evidence of radiographic bone pathology.

Prevalence rates of radiographic bone pathology observed were summarized in Table 1, while Table 2 is a summary of the number of male and female horses that showed positive for radiographic bone pathology. 


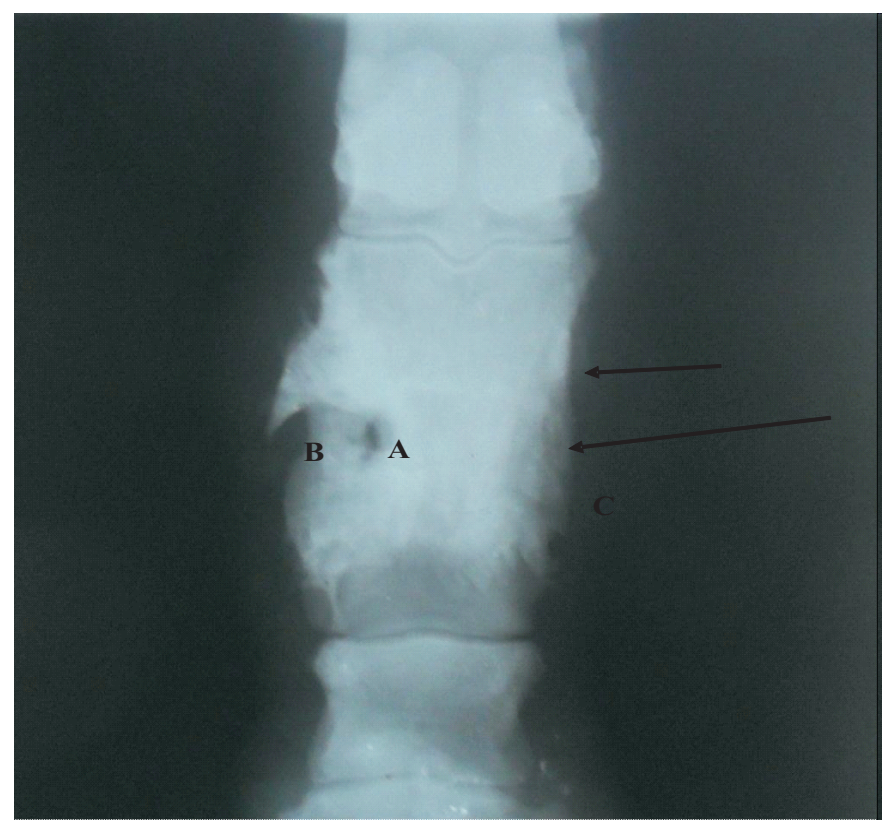

Figure 1: Posteroanterior view of the foot showing evidence of Codman triangle (black arrows), cortical bone destruction with 'moth-eaten' appearance on the diaphysis of the proximal phalanx (B), a well demarcated cystic-like lesion over the affected proximal phalanx (A) and a sun-burnst appearance on the affected bone (B).

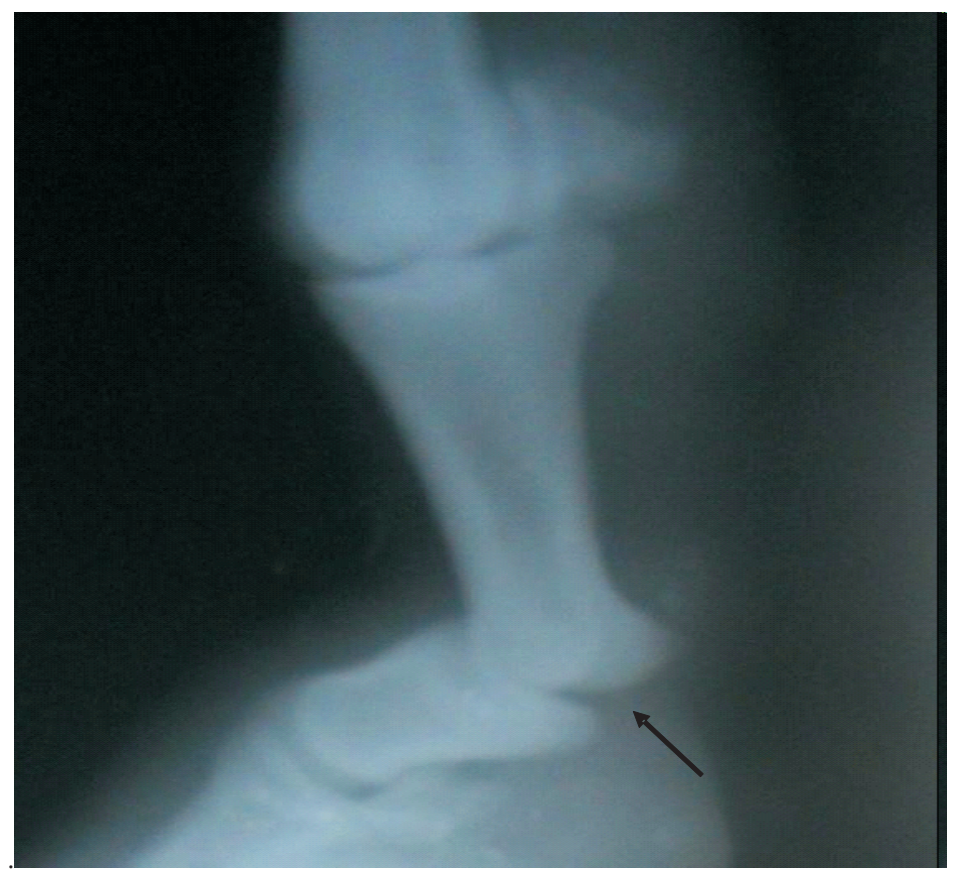

Figure 2: A lateral radiograph showing luxation of interphalangeal joints (arrow) 


\section{Ogbanya, Eze and Nnaji}

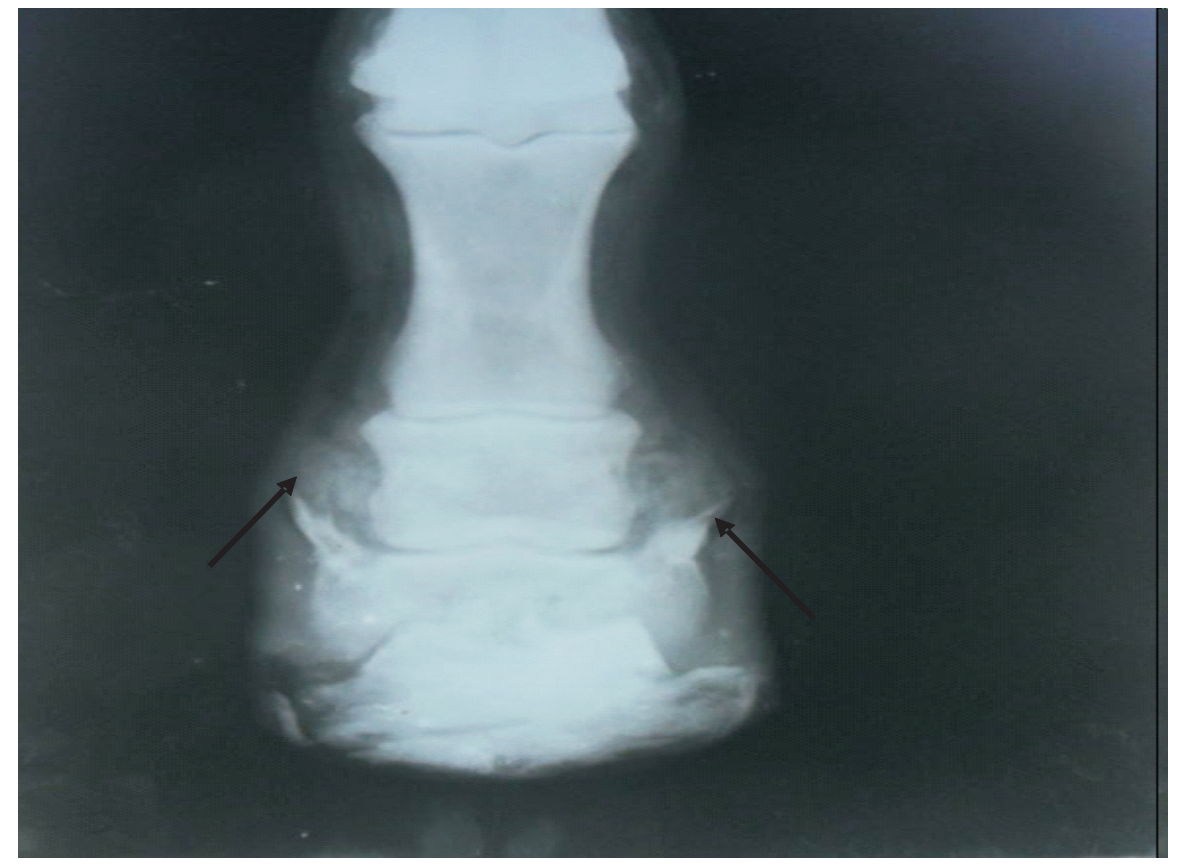

Figure 3: Dorsopalmer view of the hoof showing bilateral side bones (arrows)

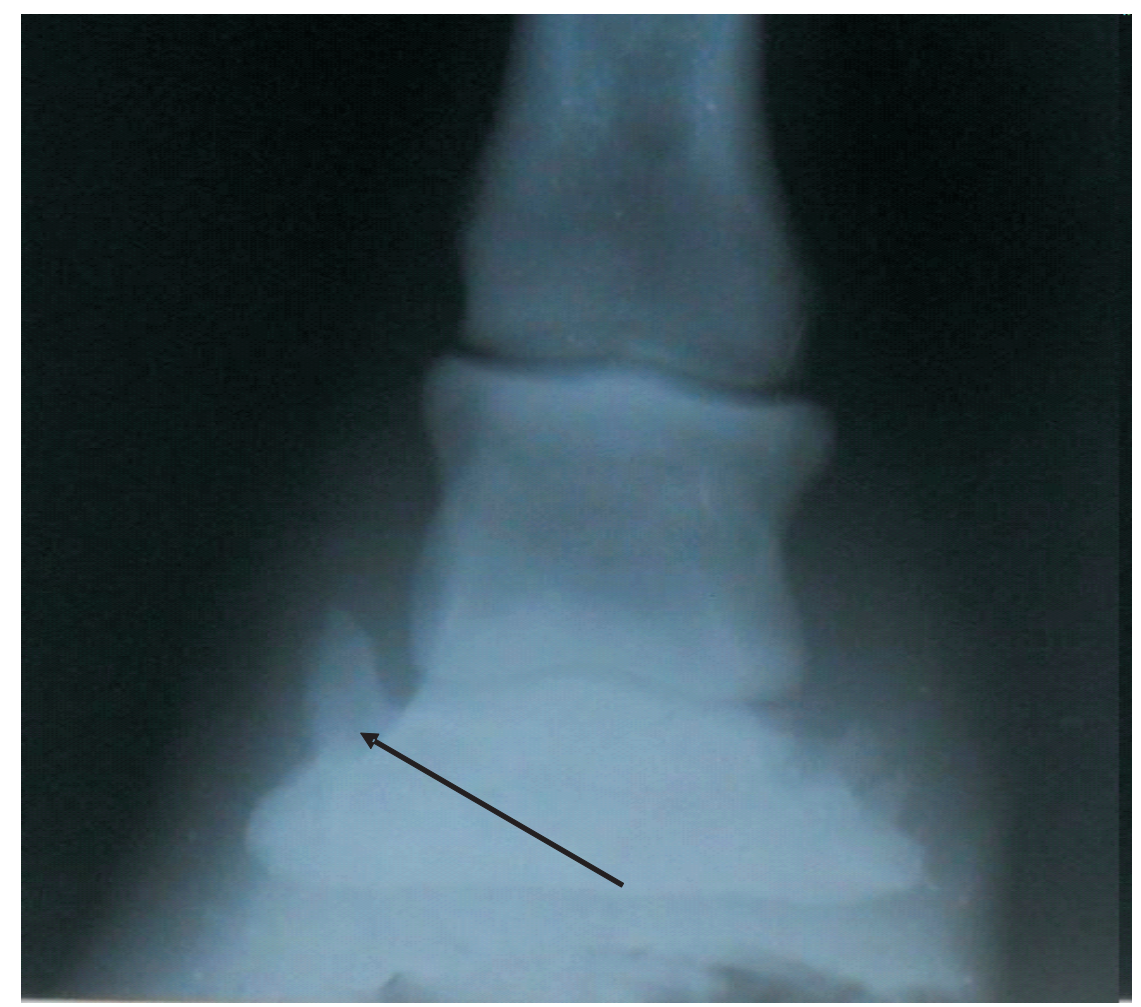

Figure 5: Ventropalmer view of the hoof showing a unilateral ossified ungular cartilages (side bone) 
Table 1: Prevalence rates of radiographic bone pathology observed in the forelimb phalanxes of Nigerian trade horses presented with footrelated forelimb lameness in Obollo-Afor horse lairage

\begin{tabular}{lll}
\hline Radiographic finding & Freq. of occurrence & Prevalence (\%) \\
\hline Neoplastic lesions & 3 & $15 \%$ \\
Interphalangeal luxation & 1 & $5 \%$ \\
Bilateral side bones & 7 & $35 \%$ \\
Unilateral side bones (TLL) & 4 & $20 \%$ \\
Total & $\mathbf{1 5}$ & $\mathbf{7 5 \%}$ \\
\hline
\end{tabular}

Table 2: Prevalent of radiographic disorders between sexes

\begin{tabular}{llll}
\hline Sex & $\begin{array}{l}\text { Number of animal } \\
\text { sampled }\end{array}$ & $\begin{array}{l}\text { Number of animal with radiographic } \\
\text { bone disorders }\end{array}$ & Prevalence \\
\hline Male & 11 & 10 & $50 \%$ \\
Female & 9 & 5 & $25 \%$ \\
Total & $\mathbf{2 0}$ & $\mathbf{1 5}$ & $\mathbf{7 5 \%}$ \\
\hline
\end{tabular}

\section{Discussion}

The observed aggressive periosteal reactive features such as 'sun-burst or sun ray appearance' along the diaphysis of the affected phalanxes and on the proximal sesamoid bones are consistent with the radiographic findings of bone neoplasia in horses (Jenner et al., 2003; Kilcoyne et al., 2010). Radiologically observed extensive area of bone lysis (osteolytic lesion), moth eaten appearance and cystic lesion of the affected first phalanx in this study were also consistent with the findings of Koch et al. (2014) of osteosarcoma of long and short bones in horses. The radiographically revealed involvement of both the medulla and cortex, with cortical disruption and radiopaque mass on the adjacent soft tissue in this study is similar to the findings of Mohd-Ariff et al. (2015) Small Cells Osteosarcoma affecting the toe phalanx in human. Similar radiological lesions were also reported in sinonasal osteosarcoma affecting the nasal cavity in a horse (Leite $e t$ al., 2019).

Luxation of proximal interphalangeal joint was radiographically confirmed in $28.6 \%$ of the sampled horses. This condition could be attributed to transportation trauma coupled with inhuman handling of the horses during unloading of the horses as they were forced to jump down from trailer.
Luxation in the horse are thought to be secondary to flexure deformities and may occur acutely secondary to collateral ligament injury (Adams et al., 1995). Interphalangeal luxation is infrequently reported in horses and is far more frequent in older and larger horses than the younger horses. The proximal interphalangeal is a low motion, high load joint, the articular cartilage bones are placed under a greater workload making this structure more susceptible to injury from nonphysiological loading (Pool and Meagher, 1990). Of the 20 horses examined, $15 \%$ of the horses had bilateral side bones while $10 \%$ of the horses had unilateral side bones. Ossification of the collateral (ungular) cartilages of the foot is called side bone (Hedenström et al., 2014). The collateral cartilages of the foot are C-shaped structures attached to the bony structures of distal phalanx (Bragulla, 1999). The cartilages extend proximally to the coronary band and in palmar direction along and sometimes beyond the distal phalanx [(Hedenström et al., 2014). They vary in size and are associated with the digital cushion and thereby playing a role to reduce concussion to structures within the foot. At birth cartilages are hyaline (Bragulla, 1999) and during the postnatal period they, like all tissues of the hoof, adapt 
to workload, i.e. bodyweight and environmental factors. The hyaline cartilage gradually becomes fibrous and sometimes this process transitions into ossification. Radiography is a gold standard for studying and confirming side bones in living horses (Kummer et al., 2004; Redden, 2003). Majority of side bones are believed to be predisposed by hereditary defect and as well as environmental factors influencing the ossification process of the collateral cartilages at an unknown time during life (Hedenström et al., 2014). Clinically, side bone has lameness impact as it causes reduced plasticity in proximal parts of the hoof capsule, thereby causing higher force amplitude in the supportive tissues when working (Körber, 1991). In all Scandinavian cold-blooded trotters, side bone is considered a problem and is mentioned as one of the top 10

reasons for lameness in cold-blooded horses (Ertola and Houttu, 2011). In Sweden, any form of side bone is disqualifying for horses of all breeds when evaluated for storage of semen, eggs or other tissues used for official gene banks (Olsen et al., 2012). In the animals of present study, the percentage occurrence of radiographic disorders of phalanges were seen more in male $(34.4 \%)$ than the female $(28.6 \%)$. The observed higher number of phalangeal disorders in male horses could be associated with sex related differences due majorly because male horses are mostly used for traction and sports than the females. However, this is contrary to Smith et al. (2005) who reported a higher percentage of radiographic disorders in female than male horses.

\section{Conclusion}

The study showed that the forelimb lameness could have been precipitated by the osteopathological conditions such as neoplasia, side bones and phalangeal luxation observed in the radiographic examinations of the lower forelimbs.

Reference

Adams, P., Honnas, C. M., Ford, T. S. and Watkins, J. P. 1995. Arthrodesis of a subluxated proximal interphalangeal joint in a horse. Equine Practice, 17: 26, 29-31.

Adams, S. B. 2016. Overview of Lameness in Horses [online]. Available at, http:/www.merckvetmanual.com/ musculoskeletalsystem/lamenessi n - h o r s e s / o v e r vi e w - of lamenessin-horses. Accessed on date [April 19, 2017].

Black, M. J., Conover, K. N. and Thomassen, M. P. 2013: equine lameness examination. [Online] a $\mathbf{y}$ a i l a b l e a t http://nebraskaequine.com/Equi n e _ L a m e n e s s _ E x a mination2.pdf accessed on [April 21, 2017].

Bragulla, H. 1999. Development of hoof cartilage with special considerations of its ossification. Dtsch Tierarztl Wochenschr, 106:87-93.

Dyson, S. and Romero, J. M. 1993. An investigation of injection techniques for local analgesia of the equine distal tarsus and proximal metatarsus. Equine Veterinary Journal, 25(1): 30-35.

Ertola, K. and Houttu, J. 2011. The Finnish horse and other Scandinavian Coldblooded trotters. In: Diagnoses and Management of Lameness in the Horse. 2nd edition. Edited by Dyson SJ, Ross.MW. Saunders, St Louis: Elsevier: 1076-1081.

Fekadu, A., Teshome, H. and Worku, T. 2015: Epidemiology of Lameness among Cart Pulling Donkeys in Hawassa City Administration, Southern Ethiopian. Academic 
Journal of Animal Diseases, 4(2): 52-59.

Garber, L. and Stanton, N. 2000. Lameness and laminitis in U.S. Horse. [Online] available athttps://www.aphis.usda.gov/ani mal_health/nahms/equine/downlo ads/equine98/Equine98_dr_Lame ness .pdf accessed on [April 21, 2017].

Greene, A. N. 2009. Horses at work: the harnessing power in industrial America. The Journal of Economic His $t$ ory. D O I : 10.1017/S002205070900120X.

Hedenström, U. O., Olsson U., Holm, A. W. and Wattle, O. S. 2014. Ossification of ungular cartilages in front feet of cold-blooded trotters--a clinical radiographic evaluation of development over time. Acta Vet Scand: 56:73.

Ihedioha, J. I. and Agina, O. A 2013. Serum biochemistry profile of Nigerian horses (Equuscaballus, linnaeus 1758). Animal Research International, 10(3): 1826-1833.

Jenner, F., Solano, M. Gliatto, J., Lavallee, S. and Heed, C. 2003. Osteosarcoma of the tarsus in a horse. Equine Veterinary Journal, 35:214-216.

Kilcoyne, I., Wilson, M., Terzo, E. and David, F. 2010. Osteosarcoma of the proximal radius in a donkey. Equine Veterinary Education, 22(3): 125-129.

Koch, E., Pack, L., Zwicker, L. A., LopezMendez, C. and Aburto, E. M. 2014. Osteosarcoma in the proximal humerus of a mare. Equine Veterinary Education, 26(8): 410-415.

Körber, H. D. 1991. Radiographic studies of ossification of the hoof cartilage of horses and its clinical evaluation. Berl Munch Tierarztl
Wochenschr, 104(10):334-340.

Kummer, M., Lischer, C., Ohlerth S., Vargas, J. and Auer, J. 2004. Evaluation of a standardised radiographic technique of the equine hoof. Schweiz Arch. Tierheilkd, 146(11):507-514.

Leite, R. O., Fabris, V. E., da Silva, E. S. M., Nogueira, G. M. and Delfiol, D. J. Z. 2019 . Sinonasal Osteosarcoma in a Horse. Acta Scientiae Veterinariae, 47(1): 1 15.

Mohd-Ariff, M. A., Ali-Noor, I., Paul., A. G. and Abdullah, S. 2015. Phalangeal Osteosarcoma Mistaken for Tuberculosis: A Case Report. Malaysian Orthopaedic Journal, 9(1): 37-40.

Olsen, H. F., Klemetsdal, G., Odegård, J. and Arnason, T. 2012. Validation of alternative models in genetic evaluation of racing performance in North Swedish and Norwegian cold-blooded trotters. Journal of Animal Breeding Genetice, 129(2):164-1670.

Pilesworth R. and Dyson S. 2015. Where does it hurt? Problems with interpretation of regional and intrasynovial diagnostic analgesia. Equine Veterinary Education, 27(11):595-603.

Pool, R. R. and Meagher, D. M. 1990. Pathologic finding and pathogenesis of racetrack injury. Veterinary Clinic. North America: Equine Practitioners, 6:1-30.

Redden, R. F. 2003. Clinical and Radiologic Examination of the Equine Foot. 49th Annual convention the American Association Equine practice, 49: 169-185.

Reilly, J. D. 1995: No hoof no horse? Equine Vet. J., 27(3): 166-168.

Smith, M. A., Walmsley, J. P. and Philip, 